\title{
United States Influence on Canadian Universities and Their Libraries
}

United States influence, through foundations and individuals, has been an important factor in the development of Canadian colleges and universities. Men and money have been provided which determined the direction of the development of the universities and the trend toward state control. Impartial American authorities provided the impetus for the expansion of the collections of university libraries.

For fifty years there existed a "brain drain" to the United States, but this has now been partially reversed.

I IN THIS YEAR of the Centennial Celebration of Confederation, Canadians are recalling the forces that have contributed significantly to the development of the country. Amid the conflicting views on the extent of United States influence on the economic life in Canada, one area of American influence on the cultural life of Canada is often overlooked-the influence upon universities and their libraries.

In the development of colleges and universities Canada has profited from the guidance of American men and from donations of American money. American influence often determined the direction of the development of the universities, the trend toward state control, and the expansion of library collections. Here was no ulterior motive of profit but a genuine desire to share the money, the knowledge, and the experience of a richer and more powerful neighbor with a young and developing nation.

The beginnings of the United States influence on Canadian higher education came after the American Revolution when many Loyalists moved to Nova Scotia, New Brunswick, and Upper and Lower Canada (now Ontario and Quebec), and brought with them some

Mr. Glazier is at the Hoover Institution, Stanford University. knowledge of leading American institutions-Harvard, Yale, and Columbia. Some of the Loyalists were graduates of American colleges or were familiar with the standards of education in the Colonies and wanted the same or better opportunities in their new-found home. Some were men of position and influence, and some were farmers and tradesmen, but all were interested in schools and colleges that would be centers not only of learning but also of loyalty to the ideals and traditions of England, which they were so eager to preserve. Thus the first American settlers who came to Canada-the Loyalists-brought a zeal for learning as well as a loyalty to the Union Jack.

The first university established in Canada and the oldest in the British overseas Dominion-King's College in Nova Scotia-was the result of the plans not of Canadians but of eighteen clergymen from the newly independent American colonies, who met in New York on March 21, 1783. They addressed a letter to Sir Guy Carleton, Governor of British North America, pointing out the necessity of establishing the Church of England among the loyal settlers of Nova Scotia and suggesting that a bishop be sent to reside there. The first two signers were the Reverend Charles In- 
glis, Rector of Trinity Church, New York, afterwards Bishop of Nova Scotia, and the Reverend Samuel Seabury, afterwards Bishop of Connecticut. Five of the clergymen met again in New York on October 18, 1783, and agreed on a plan that was forwarded to Sir Guy Carleton for "the founding of a college or seminary of learning on a liberal plan in that province [Nova Scotia], where youth may receive a virtuous education and can be qualified for the learned professions. . .." "1

The first motive of these clergymen was to maintain and strengthen the domain of the Church of England, but they were also resolved to strengthen the ties of loyalty to Great Britain. Some of these clergymen, because of their loyalty to Britain during the Revolutionary War, had suffered imprisonment or the confiscation of their property and were eager to establish a new domain of loyalty among the youth of Nova Scotia. In their covering letter to the Governor they warned him of the danger of the youth of Nova Scotia leaving home in search of higher education and coming "to some of the States of this continent, where they will be sure to imbibe principles that are unfriendly to the British Constitution."2

On May 12, 1802, a Royal Charter was given to King's College, Windsor, and the dream of its American planners was fulfilled. Born of religious and patriotic zeal, the college survived the perilous days of youth marked by a fierce struggle between over-zealous laymen who sought to impose the Thirty-Nine Articles on all students, and a wise Bishop, the same Charles Inglis who had been an original petitioner to the Governor, who realized that these tests were obnoxious to the majority of the citizens of the province.

For over a hundred years King's Col-

${ }^{1}$ Nova Scotia. Historical Society. Collections of the Nova Scotia Historical Society for the Year 18871888, VI (Halifax, N.S.: 1879- ), 123.

${ }^{2}$ Ibid. lege flourished, but on February 20, 1920 , the main building was destroyed by fire, and efforts to rebuild were unsuccessful. The Carnegie Corporation sent Kenneth Sills, president of Bowdoin College, and William S. Learned to make a preliminary survey of colleges in the Maritimes; they recommended that a considerable sum be given to King's if it would move to Halifax and become affiliated with the undenominational Dalhousie University. This offer was accepted, King's College moved to Halifax, and by 1924 the faculties of Arts and Pure Sciences were combined with those of Dalhousie; the Divinity School remained completely under the control of King's College.

Thus, one hundred and twenty years after the Royal Charter had been given to the Church of England institution which had been the dream of Loyalist clergymen of the former colonies, King's College became part of a federation with an undenominational institution-Dalhousie-thanks to the financial inducements of an American foundation.

The Carnegie Foundation really sought the federation of all Maritime colleges and universities into one institution at Halifax and was prepared to support the idea with a considerable sum. But the Baptist College, Acadia, refused to join and, rejecting the Carnegie offer of three million dollars, appealed to denominational loyalty and raised threequarters of a million dollars from its friends. This was one time when wellintentioned tangible support from the United States was spurned by intangible denominational fervor.

While United States influence on higher education in English-speaking Canada can be traced back to the beginning of the nineteenth century, for two reasons the influence on French Canadian higher education in the early years was not so marked. First, higher education in French-speaking Canada (Quebec), with a few exceptions such as McGill 
University, was supported and controlled by the Roman Catholic Church, and there was no desire for such outside support as American foundations might be willing to supply along with their attendant conditions. The Roman Catholic colleges were designed to train young men for the priesthood and a limited number of the professions and were not seeking to broaden the curriculum. Recent years, however, have seen a tremendous change in control and curriculum.

The second reason that American foundations did not penetrate the FrenchCanadian strongholds of education was the barrier of language. Because French was the language of instruction and communication, contact with the outside world was somewhat limited to those who spoke and understood French.

At the beginning of the twentieth century the United States again had a significant influence on Canadian higher education. Queen's University, Kingston, Ontario, had been granted a Royal Charter on October 16, 1841, as an arts and theological college under the control of the Presbyterian Church in Canada. With the expansion of the university, denominational funds proved inadequate. A special campaign was launched by the church to raise $\$ 500,000$. Andrew Carnegie, a Presbyterian, offered $\$ 100$,000 when $\$ 400,000$ had been secured by the church. While Mr. Carnegie was willing to have Queen's remain under Presbyterian control, the Carnegie Foundation had a different idea. The Carnegie Foundation offered financial assistance but on the condition that Queen's be freed from denominational control. The choice was now up to the Church. Finally, in June 1911, the General Assembly of the Presbyterian Church in Canada decided to make Queen's undenominational and thus "receive generous benefactions also from other sources, so that it may be enabled with every increasing efficiency to pro- mote the higher education of the nation." ${ }^{3}$ Thus, once again, it was a United States corporation that influenced the change of control and direction of a major Canadian institution from a denominational college to a national university.

"The State University is the greatest contribution made so far by the United States to higher education," said Sir Robert Falconer, president of the University of Toronto, to the Royal Society of Canada in 1930. ${ }^{4}$ Land grants for state universities had long been regarded as the appropriate solution to the financial needs of the new American universities. From the time of the Northwest Ordinance passed by the Congress of the United States in 1787 provision had been made for land grants to states entering the Union and desiring to support a university. The model provided by such American states as Michigan, Wisconsin, Missouri, Minnesota, and Illinois was an important factor in determining the formation of state universities in Canada-particularly in western Canada.

When the University of Manitoba was established in 1877 by the cooperation of three exisiting denominational colleges, the province had a population of less than 50,000 . Accordingly, friends of the university appealed to Ottawa for a grant of land, and by 1889 about 150,000 acres had been set apart.

When the University of Saskatchewan was formed in 1907 no provision was made for a land grant, but rather a fixed percentage of the consolidated revenue of the province was provided. The university thus had a measure of financial independence and was protected from the perils of political patronage.

The unique feature in the develop-

\footnotetext{
3 Canada. General Assembly, Acts and Proceedings of the General Assembly of the Presbyterian Church in Canada, 1911, (Halifax, N.S.: 1910- ), appendices p. 36.

4 Ottawa. Royal Society of Canada. Proceedings and Transactions of the Royal Society of Canada (Montreal: 1930), Ser. 3, XXIV, Sec. 2, p. 24.
} 
ment of the University of Saskatchewan was the granting to the state university of sole degree-conferring powers-a precedent which had been established by the University of Michigan. D. Pierce, father of the University of Michigan, had urged the state in 1837 to withhold charters from private colleges and to deny them the power of conferring degrees. By the Michigan constitution of 1850 the granting of charters to denominational colleges was strictly prohibited. What Pierce had advocated in 1837 and what the State of Michigan had enacted in 1850 was adopted by the new provinces of Saskatchewan and Alberta. In these provinces a single university was established under the control of, and with the support of, the state and with sole power to grant degrees, except in theology.

The new University of British Columbia also was given an endowment of two million acres of Crown lands and sole degree-conferring power.

United States influence was strong not only in determining the direction of Canadian higher education but in strengthening library resources. The early thirties were difficult years for all colleges in Canada and particularly in western Canada, where crop failures had created a serious economic plight. In 1932 the Carnegie Corporation came to the rescue of many colleges in Canada and provided $\$ 187,800$ for the purchase of books and current periodicals at the undergraduate level. These were not books for research or special collections but basic books for a college library, and grants were extended over three years. Twenty-eight institutions, from small denominational colleges such as Campion College in Regina, to state institutions such as the University of Toronto and independent universities such as Dalhousie, shared in the grants.

In the half century 1911 to 1961 the Carnegie Corporation gave nearly one million dollars for the purchase of library books and the improvement of li- brary services in Canadian colleges and universities. This included $\$ 134,300$ for the library school at McGill University and $\$ 50,000$ for the library building at Victoria University.

The Carnegie Foundation was not the only American private organization to assist materially with the development of Canadian higher education. When the Montreal Neurological Institute, the first institution in the world devoted exclusively to the treatment of nerve disease, opened on September 27, 1934, its existence was due mainly to the one million dollar grant from the Rockefeller Foundation. It was, too, an American born professor of Neurology and Neurosurgery at McGill University, Dr. Wilder Penfield, who played a leading role in its planning and became its first director. In 1964 the Ford Foundation made a grant of $\$ 100,000$ (which was matched by Canadian business and industry) to the Canadian Universities Foundation to study the financing of higher education in Canada with particular reference to the decade ending in 1975 . The report was released in October 1965.

A significant development in the libraries of Canadian universities took place as a result of a survey financed by an American institution, the Council on Library Resources, Inc., and sponsored by the National Conference of Canadian Universities and Colleges. The survey was conducted in 1962 under the direction of Edwin Williams of Harvard University, and the report of the survey was published in 1962: Resources of Canadian University Libraries for Research in the Humanities and Social Sciences. Some Canadian universities had previously borrowed experts from the United States to survey particular collections, such as the University of Toronto bringing an authority from Columbia University to evaluate its Slavic collection, but this was the first time there had been a candid look at the library resources for graduate education 
in Canadian universities. Fourteen universities were surveyed-Alberta, British Columbia, Dalhousie, Laval, McGill, McMaster, Manitoba, Montreal, New Brunswick, Ottawa, Queen's, Saskatchewan, Toronto, and Western Ontario. The surveyor's primary assignment was to report on the extent and nature of research collections for the humanities and social sciences, exclusive of Canadian material, in the fourteen universities.

The survey revealed how inadequate were the resources of Canadian university libraries for research programs. Only one library-the University of Torontohad over a million volumes. The report drew attention not only to the lack in size and depth of various subject collections but also to the fact that the amount allocated from university funds for library expenditures was entirely inadequate. As a result of the survey there has been a remarkable growth in the number of books in Canadian university libraries and an equally remarkable growth in the allocation of book funds. The report provided the catalyst that stimulated a genuine concern and produced spectacular results. Today such universities as the University of Toronto and the University of British Columbia have book budgets of over one million dollars for the current year.

American financial aid to Canadian higher education was substantial, but unintentionally it paid off as an investment. Graduates of Canadian colleges came to the United States in increasing numbers to take postgraduate studies, particularly at such prestigious institutions as Harvard, Princeton, and Yale or, in later years, at the great universities in California at Stanford, Berkeley, or Los Angeles. A large percentage of these postgraduate students stayed in the United States and accepted positions in the academic or business and professional community.

One has only to check the faculty list of any American university today to dis- cover how many professors, and even presidents (as at Stanford and San Francisco State) were born in Canada and received their first university education there. The United States has offered more opportunities and higher salaries for young Canadian graduates in academic life and also in industry.

Canada has thus had a "brain drain" problem for fifty years. The Canadian government estimates that close to ten thousand Canadians are now studying in American universities. In December 1966 the Department of Manpower and Immigration began its own "Operation Retrieval" with the distribution to students abroad of a publication describing career opportunities in Canada.

In the last ten years the brain drain to the United States has been less marked. Not only has there been an increasing number of Canadians returning to Canada, but a large number of American graduates are finding positions in Canadian economic life. This reversal of the flow is the result of the rapid growth of industrial development in Canada during and following World War II. Canada was transformed from a rural agricultural economy to an important industrial nation with a leading place in world trade. The economic development prompted the development of more colleges and universities.

Probably the most revolutionary change in Canada in the last ten years has been the significant increase in the number of new colleges and universities and the spectacular rise in enrollment. In addition to the increase in enrollment of Canadian students, more than four thousand American students are studying in Canadian universities. The expansion of colleges and universities has meant new opportunities for teaching, administration, and research for young Canadian graduates. But some of the new universities have been established and expanded so rapidly that it has not always been possible to find the faculty 
among Canadian graduates, and an increasing number of graduates from American universities are accepting teaching positions in Canadian universities. The salaries are competitive and living conditions are similar.

The new Simon Fraser University in Burnaby, British Columbia, for example, has a large percentage of Americans on the faculty. One of these Americans said recently that for him teaching in a Canadian university has been an enlightening experience, that he understands better why Canadians think the way they do, and that for the first time he sees his own country from the vantage point of a neighbor. He finds it exciting to work in an intellectual environment without the weight of encumbering traditions, where professors from England with a more conservative approach meet American professors willing to make bold experiments and where the uninhibited Canadians borrow from both to make a viable institution.

Two significant educational developments mark the Centennial Celebration in Canada this year. The first was the formal opening of the new National Library of Canada in Ottawa in June. This marked the fulfillment of years of hope that Canada would some day have a library similar in function and influence to the Library of Congress. Not only will the National Library be the nation's bibliographic center, but it will also be the repository of copies of the card catalogs of all major academic libraries in Canada and, through the aid of microfilm, will provide a vast storehouse of Canadiana. The building and the resources are worthy of the nation's treasures of the past and present.

The other development is the moving forward on the plans for the establishment of a major research library for the humanities and social sciences at the University of Toronto. Costing twenty million dollars, it will be one of the largest on the continent and will support graduate programs equal to those of the great American universities.

The Canadian Centennial Celebration in 1967 marks the completion of one hundred years of confederation of the provinces and calls to mind also the establishment of the first university in Canada one hundred and sixty-five years ago. During these intervening years Canadian higher education has received much help from the "mother" country of Britain but also a good share of men and money and knowledge from Uncle Sam.

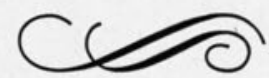

Subscribers and members who wish a blue cover to replace the green one incorrectly used on the July issue of College \& Research Libraries may obtain one of the correct color by writing to The Ovid Bell Press, Inc., 1201-05 Bluff St., Fulton, Mo. 65251. 